\title{
MINERALOGICAL EVIDENCE FOR AN OPHIOLITE FROM THE OUTOKUMPU SERPENTINITES IN NORTH KARELIA, FINLAND
}

\author{
JOUNI VUOLLO and TAUNO PIIRAINEN
}

\begin{abstract}
VUOLLO, JOUNI and PIIRAINEN, TAUNO, 1989: Mineralogical evidence for an ophiolite from the Outokumpu serpetinites in North Karelia, Finland. Bull. Geol. Soc. Finland 61, Part 1, 95-112.

The serpentinites of the Outokumpu complex located in the early Proterozoic schist belt of North Karelia in Eastern Finland are investigated petrographically, mineralogically and chemically, with an emphasis on relict minerals, especially chrome spinel, and also olivine and orthopyroxene. The relict minerals and textures provide evidence for an ophiolite of the Alpine type in the complex, and for the opinion that the serpentinites have originated from residual mantle peridotites and overlying olivine cumulates. The mantle peridotites, being serpentinized to chrysotile rocks, contain relicts of olivine $\left(\mathrm{FO}_{91-93}\right)$, orthopyroxene $(100 * \mathrm{Mg}$ / $(\mathrm{Mg}+\mathrm{Fe})=92-94)$ and anhedral, euhedral or interstitial Cr-rich chrome spinel $\left(\mathrm{Cr} /(\mathrm{Cr}+\mathrm{Al}) 0.75-0.98\right.$ and $\left.\mathrm{Mg} /\left(\mathrm{Mg}+\mathrm{Fe}^{2+}\right) 0.1-0.4\right)$, while the cumulates have been serpentinized completely to antigorite rocks, being characterized by euhedral Al-rich chrome spinel $\left(\mathrm{Cr} /(\mathrm{Cr}+\mathrm{Al}) 0.65\right.$ and $\left.\mathrm{Mg} /\left(\mathrm{Mg}+\mathrm{Fe}^{2+}\right) 0.6\right)$.
\end{abstract}

Key words: serpentinites, residual mantle peridotites, olivine cumulates, Alpine type ophiolite, Proterozoic, Outokumpu complex, Finland.

Jouni Vuollo and Tauno Piirainen: Department of Geology, University of Oulu, Linnanmaa, SF-90570 Oulu, Finland.

\section{Introduction}

The Outokumpu complex, assemblage, association or Steinmann trinity, whichever one may choose to call it, is a zone of the North Karelia schist belt in eastern Finland which is famous for its $\mathrm{Cu}-\mathrm{Zn}-(\mathrm{Co}-\mathrm{Au})$ sulfide ores. The ore critical nature of this zone, together with the problems associated with it, has meant that it has been a focus of continuous research in the fields of mineralogy, petrology, geochemistry, structural geology and ore geology ever since it was first discovered in 1910 (Frosterus and Wilkman 1920; Trüstedt 1921).
The research carried out to date provides two kinds of picture of the status of the complex within the North Karelia schist belt. One interpretation is that the zone is an autochthonous formation in a geosyncline into which magmas of mantle origin have erupted (Vähätalo 1953; Huhma and Huhma 1970; Huhma 1975, 1976; Piirainen 1969, 1976; Peltola 1978; Simonen 1980; Park and Bowes 1981; Mäkelä 1981; Bowes et al. 1984; Park 1984, 1988; Papunen 1987), while the other maintains that it is an ophiolite complex, i.e. a tectonic allochthon derived from the oceanic crust of $1.97 \mathrm{Ga}$ age (Koistinen 1981, 1986, 1987; Ward 1987), a notion which has gained support 
from research into the Kainuu schist belt (Kontinen 1987). Earlier work which also provides a basis for such a theory includes that of Wegmann (1928), Väyrynen $(1937,1939)$ and Gaal et al. (1975).

It has been known for some time that the serpentinites of the Outokumpu complex contain accessory chrome spinel and relict olivine and pseudomorphs of orthopyroxene (Haapala 1936). Haapala (op.cit.) claims that these serpentinites were originally mainly dunites and saxonites (harzburgites).

A great deal of information has accumulated at the Department of Geology, University of Oulu, in recent years on the mineral compositions of various basic and ultrabasic magmatic cumulates and the chemical compositions of their minerals (Alapieti et al. 1979a and b, 1984; Alapieti 1982; Hanski 1986; Vuollo 1986), and various ultramafiolites, including ophiolites and especially chrome spinels, have also been subject to intensive investigation elsewhere (see Greenbaum 1977; Hoffman and Walker 1978; Leblanc et al. 1983; Dick et al. 1984; Christodoulou et al. 1985; Jankovic 1986; Obradovic 1986; Johan et al. 1986; Burgath et al. 1986). This research suggests that the primary minerals in the ultramafiolites, olivine, pyroxene and above all chrome spinel, are sensitive indicators of their geological background. This makes the serpentinites of the Outokumpu complex, which have been studied surprisingly little since the work of Haapala cited above, a particularly interesting topic of investigation.

\section{Geological setting}

The Outokumpu complex contains a rock assemblage black schist - serpentinite - amphibolite - carbonate rocks - calc-silicate rocks quartz rock - $\mathrm{Cu}-\mathrm{Zn}-(\mathrm{Co}-\mathrm{Au})$ ore. It was thought earlier that it did not contain any magmatic derivatives apart from the serpentinites at all, but works carried out in recent years has led to the discovery of amphibolites with relict structures allowing them to be interpreted as gabbros, pillow lavas and pyroclastites (Park et al. 1981; Rehtijärvi et al. 1985). A date of $1.97 \mathrm{Ga}$ has been obtained from the formation from the zircon of the Horsmanaho metagabbro (Huhma 1986).

The above rock assemblage forms zones within the North Karelia schist belt which can be traced for some $260 \mathrm{~km}$ (Fig. 1). The host rocks throughout are mica schists characterized by structures typical of turbidites (Huhma 1971). These mica schists, which are regarded stratigraphically as belonging to the Kaleva series (Frosterus 1902; Frosterus et al. 1920; Väyrynen 1954; Simonen 1980) are bounded by Sariola and Jatuli quartzites (Gaal 1964, Piirainen 1968; Piirainen et al. 1974; Pekkarinen 1979; Marmo et al. 1988), overlying the Archaean basement in a discordant manner. Younger than these are the differentiated and spilitic sills and undifferentiated tholeiitic dykes (Piirainen 1969; Hanski 1986; Vuollo 1988), the age of which may be deduced from results obtained in other parts of the Karelian schist belt to be 2.2 and $2.1 \mathrm{Ga}$ respectively (see Sakko 1971; Patchett et al. 1981; Huhma 1986). The dykes cut across the Sariolan and Jatulian quartzites, but not the Kalevian schists (Väyrynen 1933; Piirainen et al. 1974).

Following the various sedimentary and magmatic events, the North Karelia schist belt underwent a complex history of deformation and metamorphism in association with the Svecokarelian orogeny around $1.9-1.8 \mathrm{Ga}$ ago. The peak of progressive metamorphism in the western parts of the formation rose as far as conditions typical of a high amphibolite facies (Treloar et al. 1981), whereas in the eastern parts it came to a halt at the boundary between the amphibolite and greenschist facies (Piirainen 1968). The deformations were also greater in number and degree in the west than in the east. Six stages of deformation have been distinguished in the Outokumpu area (Koistinen 1981), whereas only three are visible in the Koli-Kaltimo area (Kohonen 1987). Also, the schists in the west are intersected 


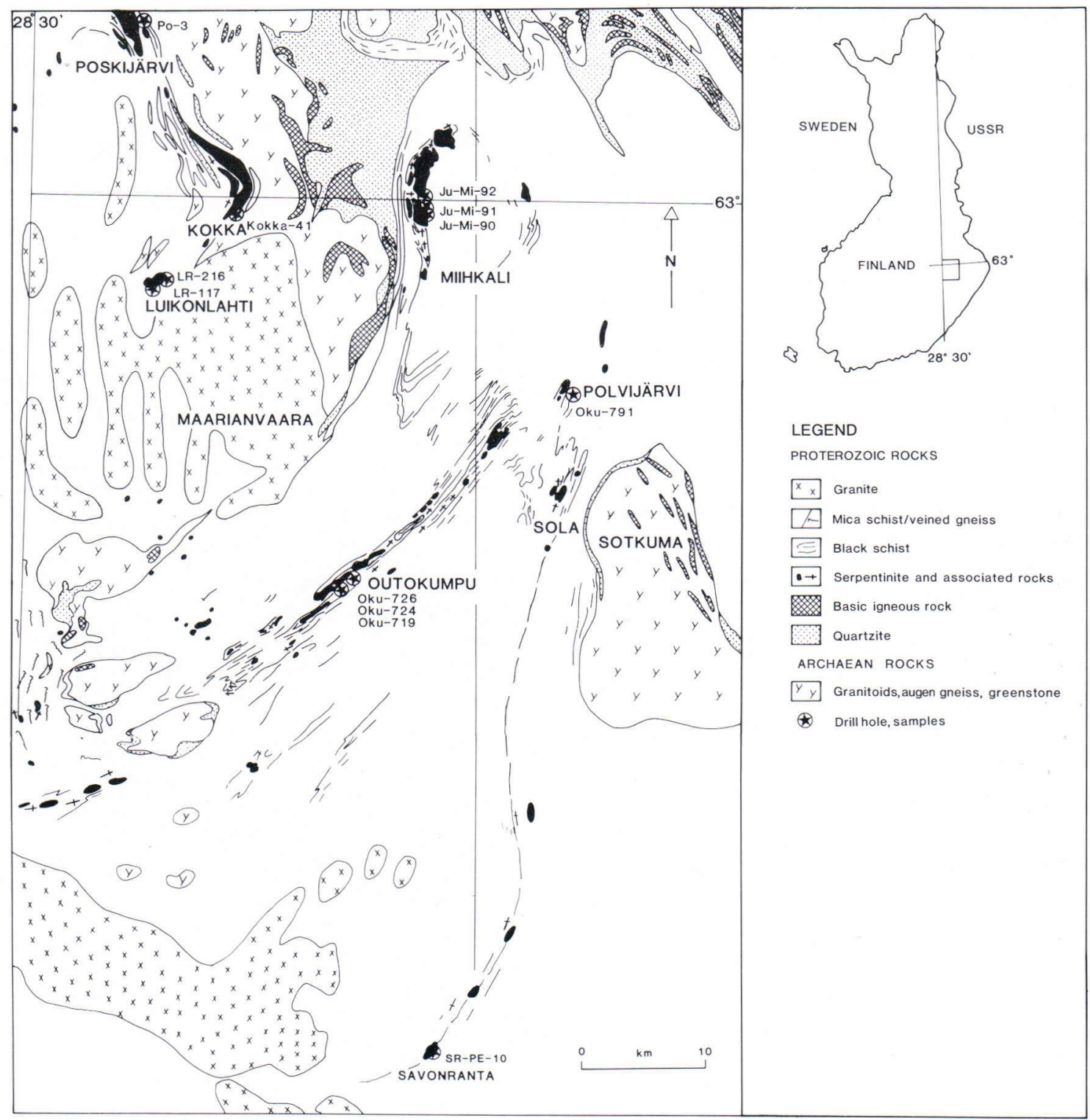

Fig. 1. Geological map of the Outokumpu area, modified after Huhma (1975), Koistinen (1981, 1987) and Parkkinen et al. (1985). The sampling sites are denoted by asterisks.

by granitoids of age $1.86-1.87 \mathrm{Ga}$ (Huhma 1986), whereas these are absent on the eastern edge of the schist belt.

In summary, the North Karelia schist belt is regarded as having gone through all the stages in the evolution model presupposed by plate tectonics, beginning after the denudation of an
Archaean mountain range with the RRR-system of the early Proterozoic and continuing to the passive margin and finally a back geosyncline (Piirainen 1968), in the same manner as described by Hoffman et al. (1974) for the Great Slave Lake area of Canada. Various interpretations have been put forward for the relation of the 
Outokumpu complex to this evolution, and we will return to these in the Discussion below.

\section{Serpentinites}

\section{General}

Serpentinites constitute the principal rock type in the Outokumpu complex, forming bodies that interleave closely with the carbonate rocks, quartz rocks and calc-silicate rocks in a conformable manner (Haapala 1936; Peltola 1978; Koistinen 1981). The individual bodies vary greatly in size and shape, the largest ones having a longitudinal axis of several kilometres and reaching thicknesses of several hundred metres. The contacts between the serpentinites and the surrounding rocks are either tectonic or gradual, grading first to carbonate rocks, which then grade via calc-silicate rocks to quartz rocks (Haapala 1936; Peltola 1978). The carbonate rocks, calc-silicate rocks and quartz rocks bordering on the serpentinite bodies have typically high $\mathrm{Cr}, \mathrm{Ni}$ and $\mathrm{V}$ concentrations (Eskola 1933; Huhma et al. 1970; Treloar 1987), and it is this that has led to the linking of their origins with the serpentinization event (Huhma et al. 1970; Gaal et al. 1975).

\section{Samples and petrography}

125 samples for investigation of the serpentinites were selected from cores obtained by Outokumpu Oy and Myllykoski Oy in connection with ore prospecting at Savonranta, Outokumpu, Polvijärvi, Miihkali, Luikonlahti, Kokka and Poskijärvi, and also from the outcrops at Mäntyjärvi in the commune of Kaavi. These sampling sites cover the whole length of the Outokumpu sequence (Fig. 1), the aim being to obtain as comprehensive a series of different types of serpentinite as possible.

\section{Savonranta}

The samples (12) were taken from different depths along a stretch of $100 \mathrm{~m}$ of core, from
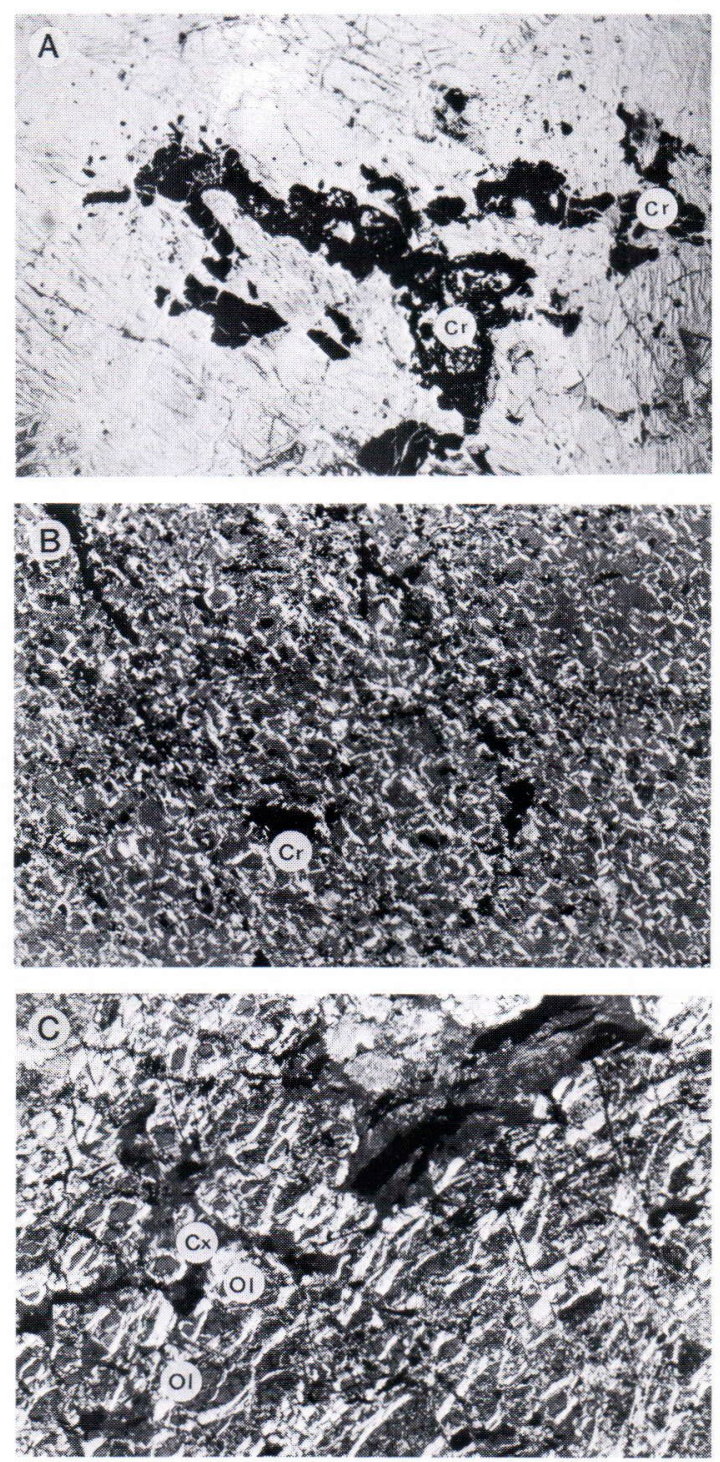

Fig. 2. Photomicrographs of a) the Savonranta harzburgite, plane polarized light, SR-PE-10, 250.00, b) the Polvijärvi antigorite serpentinite, crossed polars, OKU-791, 436.50 c) the Miihkali cumulus-textured wehrlite, crossed polars, JU-MI-92, 298.00. Ol = olivine, $\mathrm{Cr}=$ chromite and $\mathrm{Cx}=$ clinopyroxene pseudomorph. Photo length $4 \mathrm{~mm}$.

$170 \mathrm{~m}$ to $270 \mathrm{~m}$, from one borehole, SR-PE-10. The serpentinites are either dunites or harzburgites in composition (Fig. 2a). All the samples either retain the primary mineralogy in places (oli- 

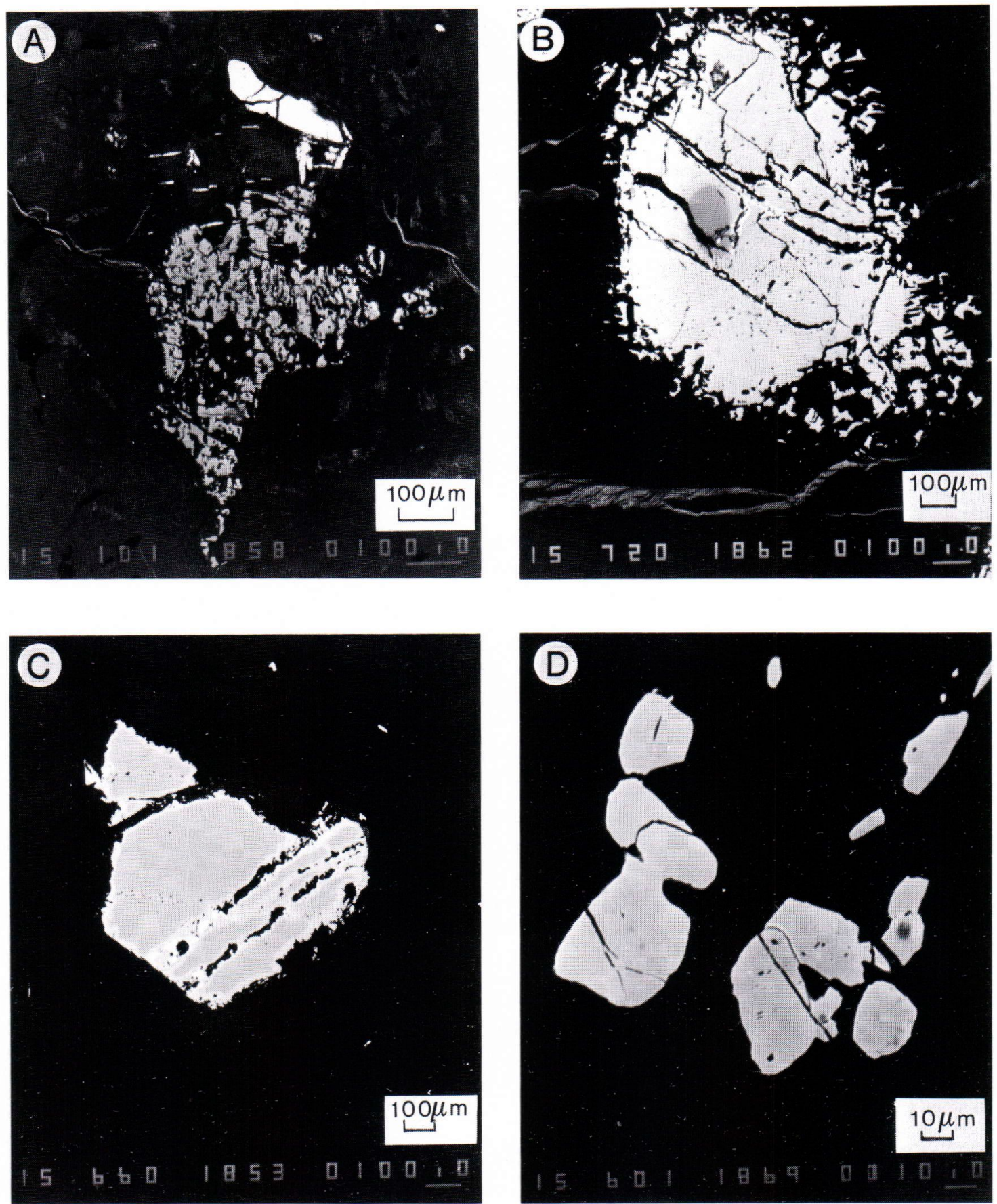

Fig. 3. SEM pictures of the chromites in the serpentinites. a) Savonranta, SR-PE-10: 192.50: an interstitial accumulation of chromite grains in which the individual grains are eroded and contain silicate inclusions, b) Polvijärvi, OKU-791: 474.30: a cumulus chromite grain which has been markedly altered so that only the centre has been preserved, c) Miihkali, JU-MI-90: 373.00: a cumulus chromite grain which has altered to a very much lesser degree than the above, d) Luikonlahti, LR-117 86.95: isolated, eroded chromite grains in a dunitic rock. 
vine, orthopyroxene and/or chromite) or else, in most cases, have pseudomorphs visible. The olivine has been replaced by chrysotile/lizardite, and the orthopyroxene by bastite. There is little orthopyroxene and it is found as anhedral grains which are very much larger $(1-5 \mathrm{~mm})$ that those of olivine. The chromite is found in dark-brown, eroded interstitial accumulations in the harzburgites and dunites (Fig. 3a), the size of these accumulations frequently exceeding $5 \mathrm{~mm}$. Individual grains are usually $<0.1 \mathrm{~mm}$ in size. Little alteration of chromite is observed, and the accumulations are surrounded by only a thin $\mathrm{Fe}$ rich margin $(<0.01 \mathrm{~mm})$.

\section{Outokumpu}

The samples (23) are from three boreholes, OKU-719: 150-515 m, OKU-724: 730-805 m and OKU-726: 315-460 m. Those from boreholes 719 and 724 represent dunitic serpentinites of cumulus texture (chrysotile/lizardite with a little antigorite), whereas borehole 726 also contains lherzolitic and harzburgitic serpentinites (chrysotile/lizardite). The primary minerals, olivine, orthopyroxene and chromite, are encountered only in borehole 726 , although their pseudomorphs are easily visible in the other cores, too. The majority of the clinopyroxene has been transformed to tremolite and then to serpentine pseudomorphs (chrysotile). Orthopyroxene relicts have been found in only one sample. Elsewhere it has been transformed mostly into bastite. The chrome spinel in boreholes 719 and 724 has been altered as far as Cr-magnetite, and it is only in borehole 726 that small, typically euhedral, almost unaltered, although sometimes eroded, chromite grains of $<0.1 \mathrm{~mm}$ are to be found.

\section{Polvijärvi}

The samples (11) are derived from one borehole, OKU-791, but from a core which extends for more than 300 metres $(430-750 \mathrm{~m})$. These are all dunitic serpentinites in composition, but differ from the other serpentinites of the Outo- kumpu complex in that the mineral replacing the olivine is a massive, non-pseudomorphic, greenish antigorite (Fig. 2b). These samples contain more talc and carbonate than the others studied here. The textural features of the rock and its primary minerals have been destroyed by serpentinization. Only the chromite has survived in small amounts in some of the samples, but this is different in occurrence (in large cumulus grains of $2-3 \mathrm{~mm}$, $\max .5 \mathrm{~mm}$ ) from the chromites found in the pseudomorphically replaced serpentinites, which are eroded and partially interstitial. Chromite alteration is zonal in character (more than half of the grains; Fig. 3b), in that the margins are rich in $\mathrm{Fe}^{3+}$ and only the core of the grain has preserved its original composition.

\section{Miihkali}

The samples (38) were selected from three cores, JU-MI-90: 130-540 m, JU-MI-91: 50$530 \mathrm{~m}$ and JU-MI-92: 300-330 m. Certain of them are chiefly composed of homogeneous dunites with olivine replaced by chrysotile. Only relicts of olivine and chromite have been preserved, but the cumulus textures are well visible (Fig. 2c). There are other samples in which the olivine has been replaced to a pronounced degree by antigorite, as at Polvijärvi. This difference in the rocks (antigorite serpentinite contra chrysotile-lizardite one) and the evident difference in stratigraphical level are reflected in the mode of occurrence of the chrome spinel and its alteration. Chromite is found in interstitial accumulations of grains in the chrysotilelizardite serpentinites, the grains $(<0.1 \mathrm{~mm})$ showing signs of pronounced erosion, whereas the chromite in antigorite serpentinites occurs in large $(>1 \mathrm{~mm})$ zonal euhedral cumulus grains (Fig. 3c).

\section{Luikonlahti}

The samples (31) were taken from two cores obtained by Myllykoski Oy, LR-117: 50—405 m, 
LR-216: 10-190 m. Judging from the pseudomorphs, the dunites, lherzolites and harzburgites are all represented in these samples. Of the minerals, only olivine and chrome spinel have survived. The orthopyroxene has been altered to bastite and the clinopyroxene to tremolite and then serpentine (chrysotile). The olivine $\left(\mathrm{FO}_{91-93}\right)$ is moderately well preserved in places and its pseudomorphs can be recognized in all the samples. Chrome spinel occurs for the most part in small, slightly eroded subhedral grains (Fig. 3d) of size $<0.1 \mathrm{~mm}$ and is preserved in practically every sample.

\section{Kokka}

The samples (3), which were chosen from one borehole, Kokka-41, are dunites in composition (chrysotile serpentinite). Apart from the chromites, the primary mineralogy has disappeared, but the pseudomorphs are still present. The chromite usually takes the form of small, subhedral, eroded grains $<0.1 \mathrm{~mm}$ in diameter.

\section{Poskijärvi}

The samples (3), from a core sequence of thirty metres, $20-50 \mathrm{~m}$, in one borehole, PO-3, are seen from the pseudomorphs present to have been dunites and lherzolites in composition. The olivine has been altered to chrysotile, the clinopyroxene to tremolite and then to chrysotile, and the orthopyroxene to bastite. Only the chromite has been preserved as eroded grains.

\section{Mäntyjärvi}

The samples (4), collected from a few outcrops to the north of Lake Mäntyjärvi, represent wehrlite in composition and their primary mineralogy has been preserved in part. The olivine $\left(\mathrm{FO}_{84}\right)$ is partly replaced pseudomorphically by chrysotile, or to a lesser extent non-pseudomorphically by antigorite. Pure cumulus grains of chromite are to be found, which have been altered to $\mathrm{Cr}$-magnetite. The clinopyroxene has been altered to tremolite and on to chrysotile.

\section{Chemistry of the serpentinites}

The material for XRF, AAS and mineral analyses was taken from samples that were as fresh as possible in appearance and in which either the primary mineralogy had been preserved in places or else the original textural features were still visible.

The various serpentinite types were analysed with respect to their main components and the trace elements $\mathrm{Cr}, \mathrm{Ni}, \mathrm{Co}$ and $\mathrm{Cu}$. Some of the types were also submitted to REE analysis. The $\mathrm{XRF}$ analyses of the main components were performed using a Philips PW 1400 instrument at the Raahe laboratories of Rautaruukki Oy and an SRM-18 analyser at the Department of Geology, University of Oulu. The trace elements were analysed with an AAS at the Raahe laboratory, and the REE analyses produced by the INAA technique at the reaction laboratories of the Finnish State Technical Research Centre. Representative results are presented in Table 1 and in the diagrams in Figs. 4 and 5.

The serpentinite samples, after removal of water and normalization to one hundred, correspond in both their main components and their trace elements to highly olivine-rich rocks, largely dunites (Fig. 4, Table 1). The $\mathrm{CaO}$ and $\mathrm{Al}_{2} \mathrm{O}_{3}$ concentrations in some types may rise so high that they correspond to harzburgites, lherzolites and wehrlites in their chemical composition, thus confirming the petrographical observations on these rocks. The rocks also correspond nearly to dunites, olivine-rich harzburgites, lherzolites and wehrlites in their normative mineral composition.

The actual and chondrite-normalized REE levels of these rocks are low (Fig. 5), the (REE) ${ }_{\mathrm{N}}$ distribution revealing a slight poverty with respect to the medium REE elements, giving a U- or Vshaped pattern. Results made by the INAAmethod will not be exact when the REE content is very low, it is however notable that they resemble the distribution obtained for the lowermost residual rocks of the Alpine ophiolite complexes (Frey 1984; Prinzhofer et al. 1985). 
Table 1. Representative whole rock analyses of Outokumpu serpentinites.

\begin{tabular}{|c|c|c|c|c|c|c|c|c|}
\hline & 1 & 2 & 3 & 4 & 5 & 6 & 7 & 8 \\
\hline $\mathrm{SiO}_{2}$ & 38.84 & 37.63 & 40.47 & 39.70 & 38.28 & 38.33 & 42.53 & 39.83 \\
\hline $\mathrm{TiO}_{2}$ & 0.02 & 0.03 & 0.04 & 0.00 & 0.03 & 0.03 & 0.03 & 0.04 \\
\hline $\mathrm{Al}_{2} \mathrm{O}_{3}$ & 0.69 & 0.87 & 0.26 & 0.24 & 0.43 & 0.35 & 1.05 & 2.85 \\
\hline $\mathrm{Fe}_{2} \mathrm{O}_{3}$ & 1.46 & 1.14 & 0.98 & 1.04 & 1.17 & 1.08 & 1.17 & 2.14 \\
\hline $\mathrm{FeO}$ & 6.55 & 5.19 & 4.33 & 4.64 & 5.30 & 4.87 & 5.07 & 9.09 \\
\hline $\mathrm{MnO}$ & 0.07 & 0.08 & 0.13 & 0.08 & 0.10 & 0.05 & 0.05 & 0.02 \\
\hline $\mathrm{MgO}$ & 40.17 & 39.28 & 39.42 & 37.80 & 38.80 & 38.41 & 30.45 & 32.97 \\
\hline $\mathrm{CaO}$ & 0.04 & 0.29 & 0.02 & 0.09 & 0.31 & 1.85 & 5.33 & 0.40 \\
\hline $\mathrm{K}_{2} \mathrm{O}$ & 0.00 & 0.03 & 0.17 & 0.00 & 0.01 & 0.05 & 0.02 & 0.03 \\
\hline $\mathrm{Cr}$ & 2700 & 1890 & 1700 & 2520 & 2380 & 2600 & 2210 & 2020 \\
\hline $\mathrm{Ni}$ & 2110 & 2080 & 2790 & 1870 & 1820 & 2030 & 2090 & 1400 \\
\hline $\mathrm{Cu}$ & 10 & 10 & 20 & 10 & 10 & 20 & 20 & 10 \\
\hline Co & n.d. & 80 & 90 & n.d. & 70 & 70 & 70 & 70 \\
\hline \multicolumn{9}{|c|}{ CIPW NORM } \\
\hline ORTHOCLASE & 0.02 & 0.18 & 1.20 & 0.01 & 0.06 & 0.36 & 0.12 & 0.18 \\
\hline ANORTHITE & 0.20 & 1.42 & 0.03 & 0.51 & 1.36 & 0.94 & 3.27 & 2.14 \\
\hline CORUNDUM & 0.70 & 0.47 & 0.10 & 0.09 & - & - & - & 2.44 \\
\hline WO-DIOPSIDE & - & - & - & - & 0.14 & 4.04 & 11.46 & - \\
\hline EN-DIOPSIDE & - & - & - & - & 0.11 & 3.29 & 9.16 & - \\
\hline FS-DIOPSIDE & - & - & - & - & 0.01 & 0.27 & 0.98 & - \\
\hline ENSTATITE & 22.44 & 21.50 & 32.51 & 36.10 & 25.08 & 17.37 & 32.53 & 37.37 \\
\hline FERROSILITE & 2.38 & 1.85 & 2.32 & 2.90 & 2.22 & 1.40 & 3.47 & 6.53 \\
\hline FORSTERITE & 63.78 & 65.74 & 56.99 & 53.32 & 62.18 & 63.96 & 32.53 & 39.58 \\
\hline FAYALITE & 7.46 & 6.24 & 4.47 & 4.71 & 6.07 & 5.70 & 3.82 & 7.62 \\
\hline MAGNETITE & 2.40 & 1.95 & 1.65 & 1.80 & 2.00 & 1.83 & 1.98 & 3.50 \\
\hline ILMENITE & 0.05 & 0.08 & 0.08 & 0.00 & 0.06 & 0.06 & 0.06 & 0.08 \\
\hline CHROMITE & 0.58 & 0.52 & 0.70 & 0.54 & 0.69 & 0.78 & 0.63 & 0.51 \\
\hline
\end{tabular}

1 = dunitic serpentinite (OKU-719 178.00), 2 = dunitic serpentinite (OKU-719 214.50), 3 = dunitic serpentinite (LR-117 402.80), 4 = harzburgitic serpentinite (SR-PE-10 250.00), 5 = dunitic serpentinite (SR-PE-10 255.00), $6=$ lherzolitic serpentinite (OKU-726 318.00), 7 = wehrlitic serpentinite (JU-MI-92 305.00), $8=$ antigorite serpentinite (OKU-791 446.90).

\section{Chemistry of the primary minerals}

The mineral determinations were carried out at the Department of Electron Optics, University of Oulu, using a JEOL JCXA 733 microprobe, by the method explained in detail in Alapieti and Sivonen (1983). Several hundred analyses were carried out and recorded in the analytical database maintained by the Department of Electron Optics. Only representative analyses are included in the tables, but the diagrams (Fig. 6-8) include additionally all those analyses which can be seen to represent unchanged minerals.

\section{Olivine}

The olivine grains analysed were all to a greater or lesser extent relicts of serpentinized grains, so that they evidently represent the olivine in the primary rocks. Attempts were made when performing the analyses to take account of the type of serpentinite and also the area from which the sample was taken. Representative olivine analyses for the various types are shown in Table 2 .

All the analysed olivine grains from dunites and harzburgites/lherzolites are characterized by a high Fo content exceeding $90 \%$. There are no 


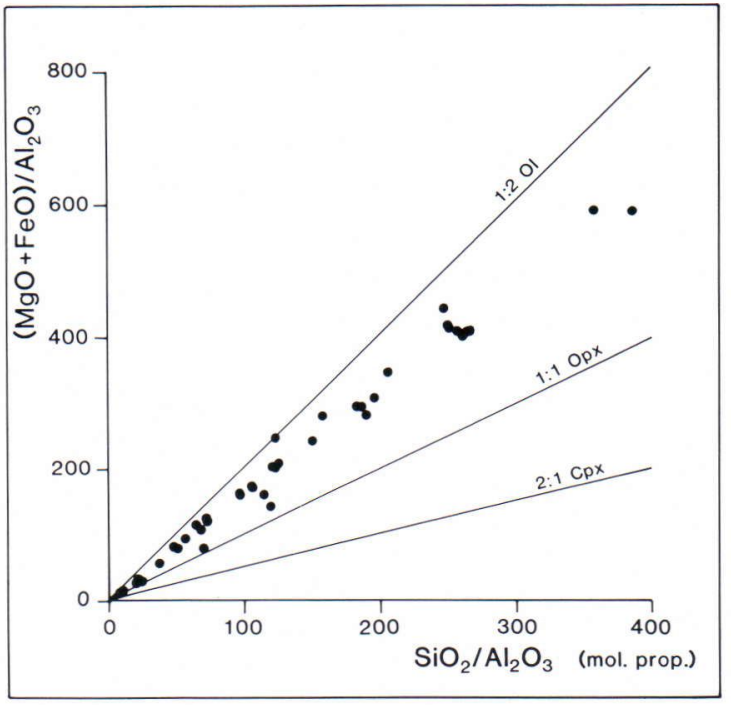

Fig. 4. $(\mathrm{MgO}+\mathrm{FeO}) / \mathrm{Al}_{2} \mathrm{O}_{3}-\mathrm{SiO}_{2} / \mathrm{Al}_{2} \mathrm{O}_{3}$ (mol.prop) plot for the serpentinites of the Outokumpu complex.

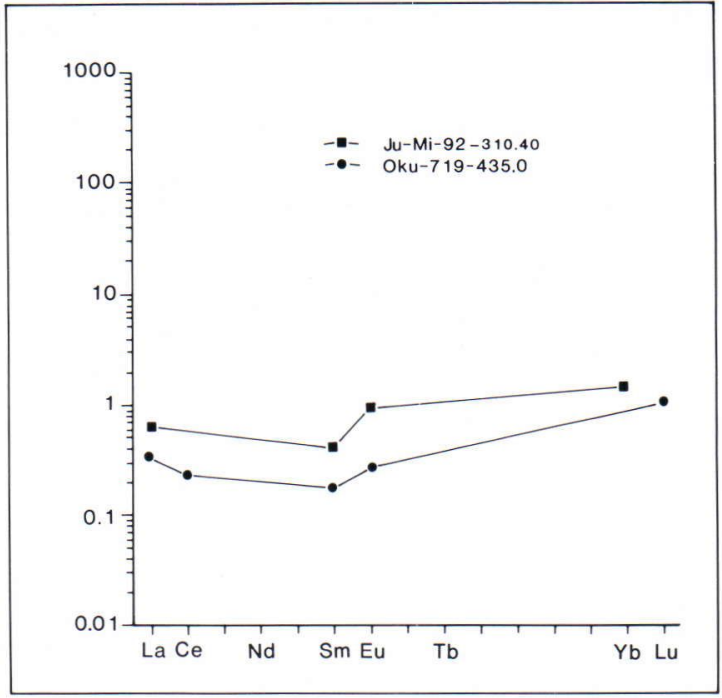

Fig. 5. Chondrite-normalized rare earth element patterns for the serpentinites of the Outokumpu complex.

Table 2. Representative microprobe analyses of olivine and orthopyroxene.

\begin{tabular}{|c|c|c|c|c|c|c|c|}
\hline & 1 & 2 & 3 & 4 & 5 & 6 & 7 \\
\hline $\mathrm{SiO}_{2}$ & 41.51 & 41.30 & 41.63 & 40.38 & 40.23 & 58.91 & 58.00 \\
\hline $\mathrm{TiO}_{2}$ & 0.03 & 0.00 & 0.00 & 0.01 & 0.03 & 0.00 & 0.01 \\
\hline $\mathrm{Al}_{2} \mathrm{O}_{3}$ & 0.00 & 0.00 & 0.00 & 0.00 & 0.01 & 0.15 & 0.46 \\
\hline $\mathrm{Cr}_{2} \mathrm{O}_{3}$ & 0.01 & 0.03 & 0.01 & 0.02 & 0.00 & 0.13 & 0.27 \\
\hline $\mathrm{FeO}$ & 6.86 & 7.24 & 8.74 & 14.53 & 14.69 & 4.41 & 4.98 \\
\hline $\mathrm{MnO}$ & 0.13 & 0.08 & 0.08 & 0.23 & 0.23 & 0.04 & 0.12 \\
\hline $\mathrm{MgO}$ & 50.88 & 50.72 & 50.33 & 45.28 & 45.04 & 36.35 & 35.25 \\
\hline $\mathrm{CaO}$ & 0.01 & 0.00 & 0.01 & 0.00 & 0.01 & 0.07 & 0.08 \\
\hline $\mathrm{NiO}$ & 0.19 & 0.12 & 0.25 & 0.29 & 0.04 & 0.05 & 0.06 \\
\hline \multirow[t]{2}{*}{ Total } & 99.61 & 99.49 & 101.05 & 100.73 & 100.28 & 100.11 & 99.25 \\
\hline & \multicolumn{5}{|c|}{ CATIONS PER 4 OXYGENS } & \multicolumn{2}{|c|}{$\begin{array}{c}\text { CATIONS PER } 6 \\
\text { OXYGENS }\end{array}$} \\
\hline $\mathrm{Si}$ & 1.0068 & 1.0044 & 1.0038 & 1.0039 & 1.0040 & 2.0051 & 1.9990 \\
\hline $\mathrm{Ti}$ & 0.0005 & 0.0000 & 0.0001 & 0.0002 & 0.0010 & 0.0000 & 0.0002 \\
\hline $\mathrm{Al}$ & 0.0000 & 0.0000 & 0.0000 & 0.0000 & 0.0000 & 0.0060 & 0.0190 \\
\hline $\mathrm{Cr}$ & 0.0002 & 0.0005 & 0.0002 & 0.0004 & 0.0000 & 0.0035 & 0.0070 \\
\hline $\mathrm{Fe}^{2+}$ & 0.1391 & 0.1474 & 0.1763 & 0.3021 & 0.3070 & 0.1256 & 0.1440 \\
\hline $\mathrm{Mn}$ & 0.0027 & 0.0017 & 0.0016 & 0.0049 & 0.0050 & 0.0012 & 0.0030 \\
\hline $\mathrm{Mg}$ & 1.8394 & 1.8386 & 1.8090 & 1.6780 & 1.6760 & 1.8440 & 1.8110 \\
\hline $\mathrm{Ca}$ & 0.0002 & 0.0001 & 0.0002 & 0.0000 & 0.0000 & 0.0025 & 0.0030 \\
\hline $\mathrm{Ni}$ & 0.0038 & 0.0024 & 0.0049 & 0.0058 & 0.0010 & 0.0013 & 0.0022 \\
\hline $\begin{array}{l}\text { Fo }(\text { mole } \%) \\
\text { mg }\end{array}$ & 92.97 & 92.58 & 91.12 & 84.74 & 84.52 & 93.62 & 92.60 \\
\hline
\end{tabular}

1 = olivine in dunitic serpentinite (LR-117 338.80), 2 = olivine in harzburgitic serpentinite (SR-PE-10 250.00), $3=$ olivine in harzburgitic serpentinite (OKU-726 327.60), $4=$ cumulus olivine in wehrlitic serpentinite (481.2-JIV-87), $5=$ cumulus olivine in wehrlitic serpentinite (JU-MI-92 298.00), 6 = relict orthopyroxene in harzburgitic serpentinite (SR-PE-10 250.00), 7 = relict orthopyroxene in harzburgitic serpentinite (OKU-726 327.60). Total Fe as FeO. $\mathrm{mg}=100 * \mathrm{Mg} /\left(\mathrm{Mg}^{2} \mathrm{Fe} \mathrm{F}^{2+}\right.$ ). 
appreciable differences in olivine composition between the dunitic and harzburgitic/lherzolitic types, but clear differences do emerge by comparison with the wehrlitic types from Mäntyjärvi and Miihkali, since the latter have Fo content of $84-85 \%$. No areal differences are found in the composition of the olivines of the various types.

The relatively high $\mathrm{NiO}$ content $(0.12-0.3 \%)$ and low values for $\mathrm{MnO}(0.06-0.25 \%)$ and $\mathrm{CaO}(0.01-0.1 \%)$ confirm the impression given by the relict petrographic features that this olivine is derived from the primary rock (cf. Fleet et al. 1977; Simkin et al. 1970; Vance et al. 1977). The $\mathrm{NiO}$ content of the olivine can reach as high as $0.3 \%$, but no clear variations can be discerned between the olivine of the various serpentinite types in this respect, although some areal differences are encountered. One striking feature is the extremely low $\mathrm{NiO}$ concentration $(0.02-0.05 \%)$ in some olivines of the Miihkali area.

\section{Orthopyroxene}

Relicts of orthopyroxene are relatively rare, being found only in the Savonranta and Outokumpu samples. Orthopyroxene can usually be identified in bastite pseudomorphs (intercumulus or poikilitic grains) at the other sites as well.

The few grains that have been found have $100 * \mathrm{Mg} /\left(\mathrm{Mg}+\mathrm{Fe}^{2+}\right)$ ratio between $92 \%$ and $94 \%$. The $\mathrm{Al}_{2} \mathrm{O}_{3}$ content is extremely low, $<0.5 \%$, but it is also low in the chromites from these samples. Analyses representative of these samples are shown in Table 2 , but the number of analyses performed is too small to permit comparison between types or sites.

\section{Chrome spinel}

Chrome spinel is the most common accessory mineral in all the serpentinite types, and has also been preserved in all the areas studied. It is therefore by far the most extensively analysed of the primary minerals in the serpentinites, so that the number of analyses covers the full range of sites and types (see Table 3). Examples of the types of chrome spinel from the various sites are shown in Fig. 3, where the chrome spinels in $3 \mathrm{a}$ and $3 \mathrm{~d}$ represent samples in which either the primary mineralogy or the pseudomorphs have been preserved (chrysotile lizardite serpentinites). Fig. $3 \mathrm{~b}$ and $3 \mathrm{c}$, on the other hand, represents samples in which the primary mineralogy and textures have been destroyed and only the chromites have survived to some extent (antigorite serpentinites).

The chromites divide into two groups in terms of composition. The small cores of eroded chrome spinel grains, occurring interstitially in places, characteristically have an extremely high $\mathrm{Cr}_{2} \mathrm{O}_{3}$ content, high $\mathrm{FeO}$ and low $\mathrm{Al}_{2} \mathrm{O}_{3}, \mathrm{MgO}$, $\mathrm{Fe}_{2} \mathrm{O}_{3}$ and $\mathrm{TiO}_{2}$, whereas the other group, the cumulus-textured chromites have been altered much more markedly and have both high $\mathrm{Cr}_{2} \mathrm{O}_{3}$ and high $\mathrm{Al}_{2} \mathrm{O}_{3}$, approx. $20 \%$ (Table 3). Their $\mathrm{MgO}$ content is also substantially higher than in the former type, while the $\mathrm{FeO}$ content is low under unaltered conditions.

In the first type the chrome spinel grain is surrounded by a thin ring with a very much higher $\mathrm{Fe}_{2} \mathrm{O}_{3}$ content than in the core. This is indicative of alteration at the grain margin, whereas evidently no change has taken place in the core, as there the $\mathrm{Fe}_{2} \mathrm{O}_{3}$ content, an increase in which is the most sensitive indicator of alteration, in the opinion of Hoffman and Walker (1978), is very low. The proportion of ferric iron among the ions filling octahedral sites is approx. $5 \%$ on average, and the ratio $\mathrm{Fe}^{3+} /\left(\mathrm{Cr}+\mathrm{Al}+\mathrm{Fe}^{3+}\right)$ is $<0.1$ and usually $<0.05$. In the second type the grains have undergone more profound alteration and the high- $\mathrm{Fe}_{2} \mathrm{O}_{3}$ margin is sufficiently thick that it accounts for more than half of the grain, although most commonly the grains have already changed to Fe-chromites or Cr-magnetites. It is for this reason that the present analyses were made on the unaltered cores of grains.

Fig. 6 depicts the chrome spinel compositions of the serpentinite samples gathered from this area on three projections of the spinel prism 
Table 3. Representative microprobe analyses of chrome spinel.

\begin{tabular}{|c|c|c|c|c|c|c|c|c|c|c|}
\hline & 1 & 2 & 3 & 4 & 5 & 6 & 7 & 8 & 9 & 10 \\
\hline $\mathrm{SiO}_{2}$ & 0.03 & 0.06 & 0.07 & 0.04 & 0.02 & 0.04 & 0.06 & 0.02 & 0.03 & 0.03 \\
\hline $\mathrm{TiO}_{2}$ & 0.05 & 0.38 & 0.04 & 0.32 & 0.13 & 0.67 & 0.05 & 0.26 & 0.02 & 0.26 \\
\hline $\mathrm{Al}_{2} \mathrm{O}_{3}$ & 3.88 & 17.18 & 18.26 & 3.36 & 11.31 & 6.17 & 19.97 & 8.80 & 6.30 & 10.02 \\
\hline $\mathrm{Cr}_{2} \mathrm{O}_{3}$ & 63.14 & 47.85 & 50.07 & 61.65 & 52.97 & 59.33 & 45.08 & 57.64 & 62.30 & 55.52 \\
\hline $\mathrm{Fe}_{2} \mathrm{O}_{3}$ & 1.76 & 1.42 & 2.73 & 3.29 & 3.50 & 2.71 & 3.63 & 3.00 & 1.74 & 2.71 \\
\hline $\mathrm{FeO}$ & 24.63 & 28.44 & 12.44 & 26.44 & 23.10 & 24.21 & 22.73 & 22.11 & 20.68 & 22.01 \\
\hline $\mathrm{MnO}$ & 0.47 & 0.16 & 0.19 & 0.46 & 0.39 & 0.47 & 0.33 & 0.47 & 0.47 & 0.34 \\
\hline $\mathrm{MgO}$ & 4.41 & 4.13 & 14.60 & 3.27 & 5.47 & 5.44 & 7.51 & 6.77 & 7.46 & 7.05 \\
\hline $\mathrm{NiO}$ & 0.00 & 0.13 & 0.16 & 0.02 & 0.01 & 0.03 & 0.01 & 0.01 & 0.00 & 0.02 \\
\hline $\mathrm{ZnO}$ & 0.78 & 0.31 & 0.11 & 1.25 & 1.91 & 0.78 & 0.97 & 1.34 & 0.55 & 0.46 \\
\hline \multirow[t]{2}{*}{ Total } & 99.40 & 100.16 & 99.19 & 100.47 & 99.08 & 100.28 & 100.34 & 100.42 & 99.98 & 99.00 \\
\hline & \multicolumn{10}{|c|}{ CATIONS PER 32 OXYGENS } \\
\hline $\mathrm{Si}$ & 0.0094 & 0.0149 & 0.0165 & 0.0106 & 0.0052 & 0.0097 & 0.0165 & 0.0038 & 0.0068 & 0.0085 \\
\hline $\mathrm{Ti}$ & 0.0105 & 0.0752 & 0.0809 & 0.0698 & 0.0258 & 0.1394 & 0.0095 & 0.0530 & 0.0039 & 0.0529 \\
\hline $\mathrm{Al}$ & 1.3039 & 5.4013 & 5.3722 & 1.1288 & 3.6608 & 2.0197 & 6.0502 & 2.8497 & 2.0359 & 3.2218 \\
\hline $\mathrm{Cr}$ & 14.223 & 10.093 & 9.8800 & 13.916 & 11.501 & 13.020 & 9.1639 & 12.519 & 13.495 & 11.971 \\
\hline $\mathrm{Fe}^{3+}$ & 0.3774 & 0.2844 & 0.5125 & 0.7061 & 0.7241 & 0.5656 & 0.7020 & 0.6207 & 0.3586 & 0.5554 \\
\hline $\mathrm{Fe}^{2+}$ & 5.8673 & 6.3443 & 2.5966 & 6.3122 & 5.3062 & 5.6206 & 4.8874 & 4.8486 & 4.7392 & 5.0188 \\
\hline Mn & 0.1137 & 0.0357 & 0.0408 & 0.1107 & 0.0916 & 0.1098 & 0.0727 & 0.1098 & 0.1084 & 0.0774 \\
\hline $\mathrm{Mg}$ & 1.8740 & 1.6410 & 5.4311 & 1.3906 & 2.2406 & 2.2523 & 2.8798 & 2.7719 & 3.0464 & 2.8665 \\
\hline $\mathrm{Ni}$ & 0.0000 & 0.0280 & 0.0324 & 0.0040 & 0.0010 & 0.0060 & 0.0030 & 0.0010 & 0.0000 & 0.0040 \\
\hline $\mathrm{Zn}$ & 0.1650 & 0.0620 & 0.0206 & 0.2830 & 0.3920 & 0.1620 & 0.1850 & 0.2720 & 0.1130 & 0.0340 \\
\hline $\mathrm{Mg} /\left(\mathrm{Mg}+\mathrm{Fe}^{2+}\right)$ & 0.2421 & 0.2055 & 0.6765 & 0.1805 & 0.2969 & 0.2861 & 0.3708 & 0.3640 & 0.3913 & 0.3635 \\
\hline $\mathrm{Cr} /(\mathrm{Cr}+\mathrm{Al})$ & 0.9160 & 0.6514 & 0.6477 & 0.9250 & 0.7586 & 0.8657 & 0.6023 & 0.8146 & 0.8689 & 0.7879 \\
\hline $\mathrm{Fe}^{3+} /\left(\mathrm{Cr}+\mathrm{Al}+\mathrm{Fe}^{3+}\right)$ & 0.0237 & 0.0180 & 0.0325 & 0.0448 & 0.0456 & 0.0362 & 0.0441 & 0.0388 & 0.0226 & 0.0353 \\
\hline
\end{tabular}

$1=$ chrome spinel in lherzolitic serpentinite (OKU-726 318.00), 2 = cumulus chrome spinel in dunitic serpentinite (OKU-791 474.30), 3 = cumulus chrome spinel in dunitic serpentinite (OKU-791 474.30), 4 = chrome spinel in dunitic serpentinite (LR-117 81.10), 5 = chrome spinel in dunitic serpentinite (LR-117 86.95), 6 = chrome spinel in dunitic serpentinite (LR-216 152.70), 7 = cumulus chrome spinel in dunitic serpentinite (JU-MI-90 373.50), 8 = chrome spinel in dunitic serpentinite (JU-MI-90 130.85), 9 = interstitial chrome spinel in harzburgitic serpentinite (SR-PE-10 172.90), $10=$ interstitial chrome spinel in dunitic serpentinite (SR-PE-10 255.30).

(Stevens 1944). In Fig. 6a the best preserved of the chromites, that found at Savonranta has a $\mathrm{Cr} /(\mathrm{Cr}+\mathrm{Al})\left[\right.$ later $\mathrm{X}_{\mathrm{Cr}}$ ] ratio of $0.7-0.9$ and a $\mathrm{Mg} /\left(\mathrm{Mg}+\mathrm{Fe}^{2+}\right)$ [later $\mathrm{X}_{\mathrm{Mg}}$ ] ratio diminishing from 0.4 to 0.2 as $\mathrm{Cr}$ increases. The main changes in composition in the Outokumpu samples compared with Savonranta are a decrease in $\mathrm{Al}$ content and an increase in $\mathrm{Fe}\left(\mathrm{X}_{\mathrm{Cr}}>0.9\right.$ and $\mathrm{X}_{\mathrm{Mg}}$ between 0.4 and 0.2 ). The chrome spinels of Miihkali fall into two groups: The cumulus chromites have $\mathrm{X}_{\mathrm{Cr}} 0.6$ and $\mathrm{X}_{\mathrm{Mg}} 0.4$, whereas the interstitial grains have values of $0.8-0.9$ and $0.4-0.2$ respectively. The composition of the $\mathrm{Cr}$-rich chrome spinels alter in the same manner as at
Savonranta. The Polvijärvi chromites form a clearly defined group of their own along with the Miihkali cumulus chromites, having $\mathrm{X}_{\mathrm{Cr}} 0.6-$ 0.65 , a ratio which remains virtually unchanged as $\mathrm{X}_{\mathrm{Mg}}$ varies in the range $0.65-0.2$, sometimes within the same sample. $\mathrm{X}_{\mathrm{Cr}}$ for the Luikonlahti, Kokka and Poskijärvi chrome spinels is in the range $0.75-0.95$ and $\mathrm{X}_{\mathrm{Mg}}$ in the range $0.4-0.2$. These also present the same kind of change in composition as at Savonranta and in the Cr-rich chromites at Miihkali.

Taken all in all, the chrome spinels fall into two groups regarding their $\mathrm{X}_{\mathrm{Cr}}$ and $\mathrm{X}_{\mathrm{Mg}}$ ratios. Generally $\mathrm{X}_{\mathrm{Cr}}$-values are high, 0.7-0.95 and 

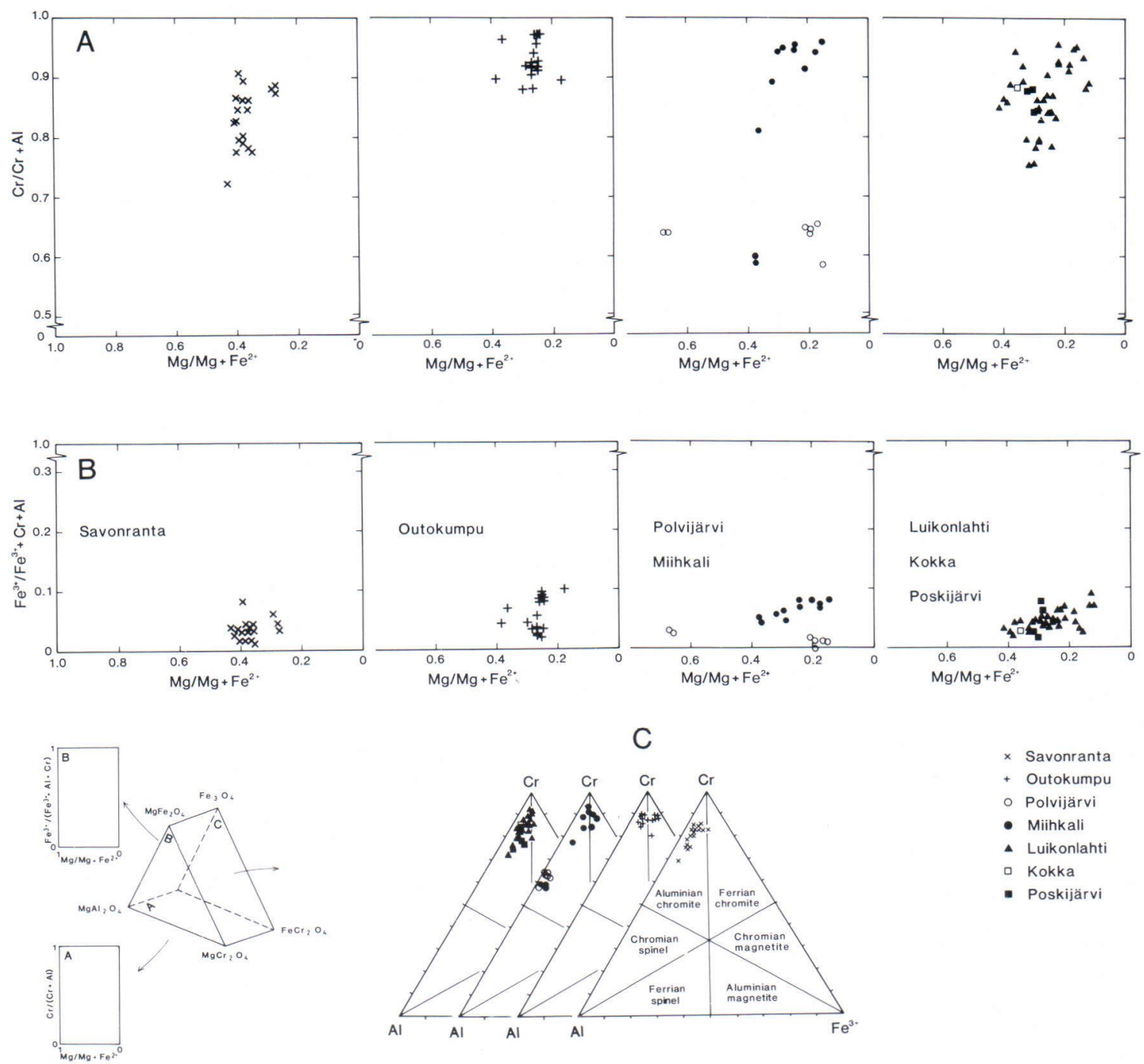

$\times$ Savonranta

+ Outokumpu

○ Polvijärvi

- Miihkali

- Luikonlahti

- Kokka

- Poskijärvi

Fig. 6. Composition of chrome spinels from the Outokumpu complex. The results are plotted on projections of the spinel prism for chemical composition (after Stevens 1944).

$\mathrm{X}_{\mathrm{Mg}}$ being $0.4-0.2$ irrespective of the degree of alteration, except in Polvijärvi and few Miihkali samples in which $X_{C r}$ remains evenly around 0.6 while $\mathrm{X}_{\mathrm{Mg}}$ varies greatly, from 0.65 to 0.2 . An extremely low $\mathrm{Fe}^{3+}$ content is generally to be seen on the $\mathrm{Fe}^{3+} /\left(\mathrm{Fe}^{3+}+\mathrm{Cr}+\mathrm{Al}\right)$ diagrams (Fig. 6b), resulting in a low value for the ratio, $<0.1$.

The Savonranta chromites are located in the $\mathrm{Al}$-chromite field close to the $\mathrm{Cr}$ corner of the
$\mathrm{Cr}: \mathrm{Al}: \mathrm{Fe}^{3+}$ triangle (Fig. $6 \mathrm{c}$ ), while the slightly altered Outokumpu chromites, having undergone an increase in $\mathrm{Fe}^{3+}$ and a loss of $\mathrm{Al}$, lie in the field of either the Al-chromites or the $\mathrm{Fe}$ chromites. The Al-chromites at Miihkali fall into two groups depending on their texture, the large cumulus chromites rich in $\mathrm{Al}$ closer to the $\mathrm{Al}$ corner, whereas the small interstitial chromites rich in $\mathrm{Cr}$ closer to the $\mathrm{Cr}$ corner. Only the cumulus chromites are represented in the Polvijärvi sam- 
ples, these being found in the same area as the Miihkali cumulus chromites. The chromites of the westernmost area, Luikonlahti, Kokka and Poskijärvi, are all rich in $\mathrm{Cr}$, lying in the $\mathrm{Al}$ chromite field in the $\mathrm{Cr}$ corner.

The results (Fig. 6c) therefore point to a clear binary division among the chrome spinels, the cumulus chromites lying closer to the $\mathrm{Al}$ corner of the diagram and the small, eroded, locally interstitial grains in the metallurgical chromite field only a short distance from the $\mathrm{Cr}$ corner.

\section{Discussion}

Two distinct lines of interpretation can be distinguished in research into the Outokumpu complex, as mentioned at the beginning of this paper. Descriptions of its structural geology show it to be part of a tectonic allochthon in connection with which a portion of ocean floor of age $1.97 \mathrm{Ga}$ moved in the course of orogenic upheavals around 1.8-1.9 Ga ago to form an ophiolite complex in the area of the North Karelia schist belt. In contrast to the ophiolite interpretation, it may also be claimed that the Outokumpu complex merged with the Kalevan mica schists, which are not allochthonous, and therefore the complex itself cannot be ophiolite of the kind described above, but must be part of a geosyncline into which magmas from the mantle must have erupted. Both interpretations have strong arguments in their favour (see Introduction).

Nowadays the notion put forward by Borchert (1954) is generally accepted, that the ore deposits associated with the complex are submarine exhalation ores connected genetically with the magmatic rocks of the same association (Mäkelä 1974; Peltola 1978; Mäkelä 1981). The ore must thus resemble either the Besshi or the Cyprus type, depending on whether the association is taken to be part of a geosyncline vulcanism or an ophiolite complex. The carbonate rocks and quartz rocks of the complex have been in- terpreted as chemical sediments connected genetically with the serpentinization event (Huhma et al. 1970; Gaal et al. 1975; Huhma 1976).

In view of the relict minerals in the serpentinites and of the composition of these rocks, it may be concluded that they must have originally been dunites, harzburgites, lherzolites and wehrlites. Serpentinization was evidently an isochemical event, as shown by the discrimination diagram $(\mathrm{MgO}+\mathrm{FeO}) / \mathrm{Al}_{2} \mathrm{O}_{3}-\mathrm{SiO}_{2} / \mathrm{Al}_{2} \mathrm{O}_{3}$ (Fig. 4). All the serpentinite samples analysed here were located either on or below the discrimination line for olivine but not above it, indicating that no appreciable amounts of $\mathrm{SiO}_{2}$ had left the rock. In that case an explanation for the chemical sediments has to be sought elsewhere and not in the serpentization event.

The serpentinites of the western zones are characterized by either relicts or pseudomorphs of olivine and orthopyroxene and pseudomorphs of clinopyroxene. The olivine typically has a high Fo content $\left(\mathrm{FO}_{91-93}\right)$, as is normally found only in the residual parts of ophiolites. The $\mathrm{Mg}$-ratio of the orthopyroxene is $92-94$, which also corresponds to ophiolite values, and its $\mathrm{Al}_{2} \mathrm{O}_{3}$ content is extremely low, $<0.5 \%$, as also in the chromites from these samples. The $\mathrm{Al}_{2} \mathrm{O}_{3}$ concentrations in the relevant minerals in these samples are well balanced by comparison with figures quoted for other ophiolites (cf. Johan et al. 1986).

The primary mineral which is perhaps the most sensitive indicator of its origins is the chrome spinel, the octahedral sites in which are filled chifly by $\mathrm{Cr}, \mathrm{Al}$ and $\mathrm{Fe}^{3+}$ and the tetrahedral sites by $\mathrm{Mg}$ and $\mathrm{Fe}^{2+}$, its composition being dependent on concentration ratios, pressure, temperature and the fugacity of oxygen. Increased pressure will reduce the $\mathrm{Cr} / \mathrm{Al}$ ratio of the mineral, while increased $\mathrm{SiO}_{2}$ will have the opposite effect (Dick et al. 1984). High iron content $\left(\mathrm{Fe}^{3+}\right)$ reflects alteration (Hoffman and Walker 1978).

The chrome spinels of the western zones are most often subhedral in texture, eroded and in- 
terstitial in places. They frequently have a $\mathrm{Cr}_{2} \mathrm{O}_{3}$ content in the region of $60 \%$ and a low $\mathrm{Al}_{2} \mathrm{O}_{3}$ content, $<10 \%$. Thus their $\mathrm{X}_{\mathrm{Cr}}$ ratio is in the range $0.75-0.98$ and their $\mathrm{X}_{\mathrm{Mg}}$ ratio $0.1-0.4$. In the best preserved harzburgite, that of Savonranta, where the least evidence of alteration was seen, the ratio $\mathrm{X}_{\mathrm{Cr}}$ was $0.7-0.9$ and $\mathrm{X}_{\mathrm{Mg}}$ $0.3-0.4$. These ratios are quite distinct from those found in either abyssal ultramafiolites, the chrome spinels of layered intrusions, or those of the ultramafic cumulates of tholeiitic, picritic and komatiitic parent magmas. They show an almost exact correspondence in both texture and composition with the lowermost ultramafic chrome spinels in ophiolite complexes such as those reported in the Bay of Islands, Canada (Malpas et al. 1975), at Brezovica, Orahovac and Radusa/ Ljuboten, Yugoslavia (Obradovic 1986), at Orhaneli, Turkey (Tankut 1980), at Palawan in the Philippines (Rammlmair 1986), and at Josephine in the U.S.A. (Dick 1977), all of which are interpreted as residuals from the mantle (Fig. 7). The $\mathrm{X}_{\mathrm{Mg}}$ ratio of the chrome spinels of the Outokumpu complex is slightly lower than that reported in the Orhaneli or at Palawan, but compares well with that of the Bay of Islands and Brezovica chromites.

The $\mathrm{X}_{\mathrm{Cr}}$ ratio in the eastern zone is of the order of 0.65 , which is slightly higher than in abyssal peridotites, but corresponds entirely with the chrome spinel composition of cumulates in ophiolite complexes. The $\mathrm{X}_{\mathrm{Mg}}$ ratio gains values of $0.65,0.4$ and $0.1-0.2$, the first two of which correspond to figures reported for chrome spinels in the ultramafic cumulates of ophiolite complexes, whereas the last-mentioned range differs markedly, the samples containing very much more $\mathrm{Fe}^{2+}$ in tetrahedrally coordinated sites. The first value corresponds to primary chrome spinels and the latter to ones that have been altered to various degrees. This suggests that if any alteration has taken place, it has consisted only of an increase in $\mathrm{Fe}^{2+}$ concentration at the expense of $\mathrm{Mg}$ in the tetrahedral sites, with no change in the ratio of ions in the octahedral sites.

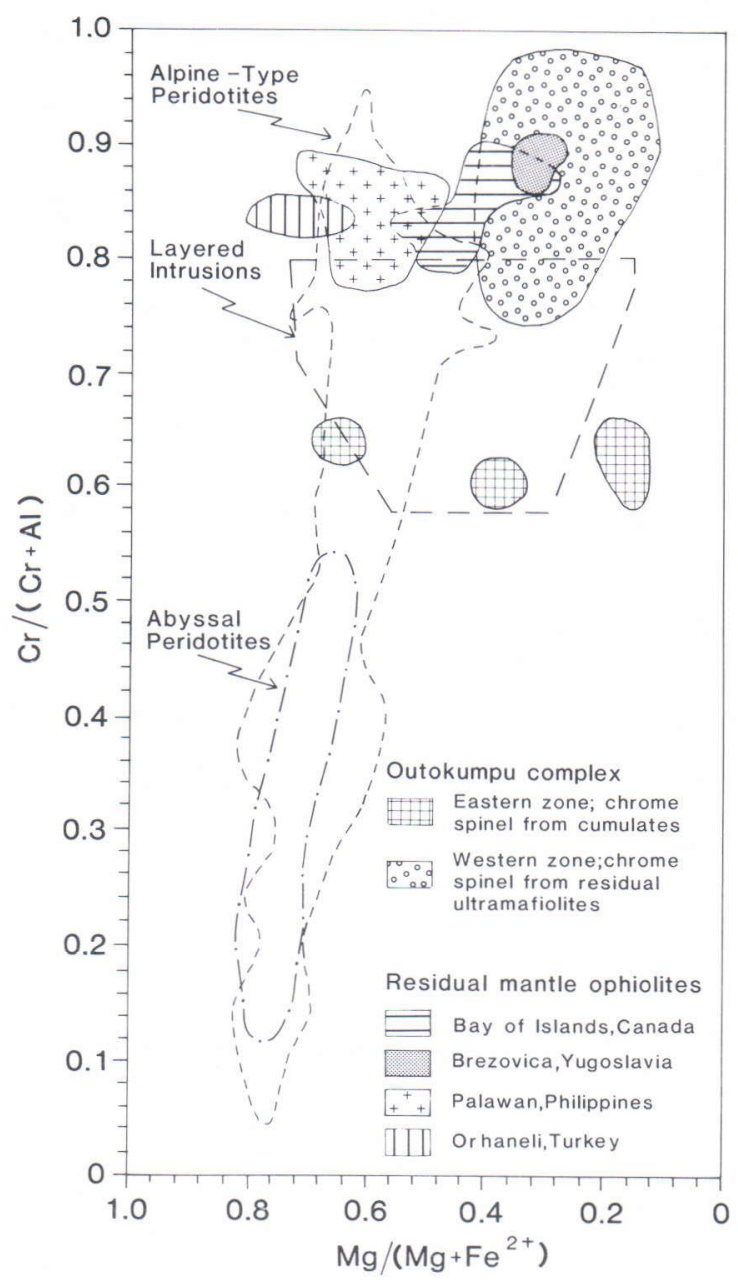

Fig. 7. Composition fields of chrome spinels from the Outokumpu complex (from this study) and in Alpine-type peridotites, abyssal peridotites (Dick et al. 1984), layered intrusions (Irvine, 1967). Some fields are from residual mantle ophiolites in: Bay of Islands (Malpas et al. 1975); Brezovica (Obradovic 1986); Palawan (Rammlmair 1986); and Orhaneli (Tankut 1980).

All the chromite analyses from the Outokumpu complex are located on a $\mathrm{Cr}: \mathrm{Al}: \mathrm{Fe}^{3+} \mathrm{dia}-$ gram in Fig. 8, on which the compositions of stratiform and podiform chromites are also indicated after Dickey (1975). The majority of the chromites from the western zones lie in the metallurgical chromite field close to the $\mathrm{Cr}$ corner, on account of their high $\mathrm{Cr}$ content, while 


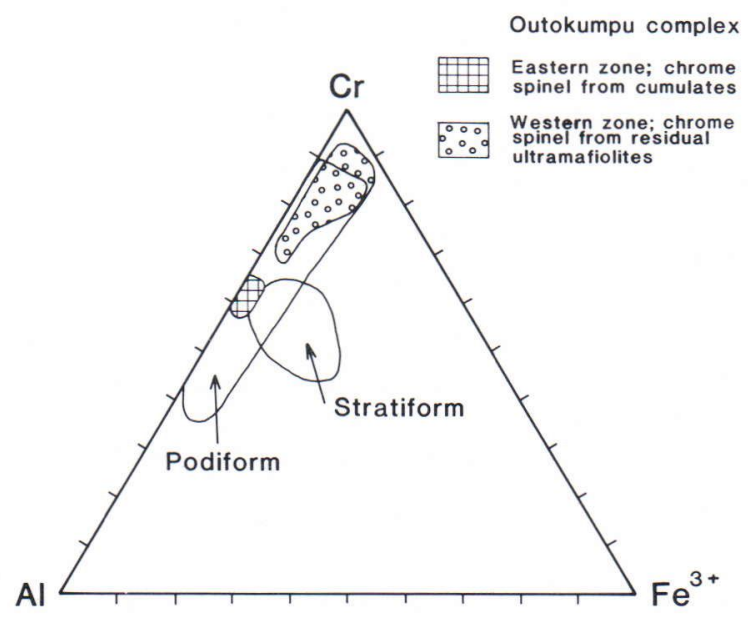

Fig. 8. $\mathrm{Cr}: \mathrm{Al}: \mathrm{Fe}^{3+}$ diagram for the chrome spinels of the Outokumpu complex. The fields of stratiform and podiform chrome spinels are defined after Dickey (1975).

chromites from the best preserved serpentinites, those from Savonranta, are located entirely in the field of the podiform chromites. The chromites of the eastern zone, including those of Miihkali, also lie in the podiform chromite field, but are very much richer in $\mathrm{Al}$ and therefore tend to group towards the $\mathrm{Al}$ corner.

The search for analogies to the serpentinites of the Outokumpu complex on the basis of the relict minerals, olivine, orthopyroxene and in particular chrome spinel, leads in the case of the western zones to the lowermost parts of ophiolite complexes, which are generally considered to represent the residual mantle, and in the case of the eastern zone to the olivine cumulates of the upper parts of ophiolite complexes. Both parts would appear to be represented at Miihkali, as is clearly detectable from both the texture and the composition of the chromites.

A further argument for a residual origin for the ultramafiolites of the western zones is also found in the $(\mathrm{REE})_{\mathrm{N}}$ distribution, which is of the same form as has been found in such residuals (Frey 1984; Prinzhofer et al. 1985).

\section{Conclusions}

The primary minerals in the serpentinites of the Outokumpu complex, especially the chrome spinel and also the olivine and orthopyroxene to a great extent, argue for the interpretation which sees the formation as an ophiolite complex which contains serpentinites derived both from the residual mantle and from cumulates.

The residual mantle serpentinites were originally dunites, harzburgites and lherzolites, while the cumulates were dunites and wehrlites. Serpentinization in the parts of the formation representing the residual mantle progressed in a manner which preserved the original textural features of the rocks and lead to the creation of lizardite and chrysotile, whereas in the cumulates the original textural features were obliterated almost entirely as the rocks were transformed to antigorite serpentinites. Serpentinization was an isochemical process in both cases except for the addition of water. The serpentinites that originated from the residual mantle are predominant in the western parts of the area, while the cumulate types dominate the eastern zone. Both types are in evidence at Miihkali.

Acknowledgements. This paper was produced as a part of the investigations of the North Karelia Research Project at the Department of Geology, University of Oulu, financed by the Ministry of Trade and Industry (Inspector U. J. Salo). The authors are grateful to the Outokumpu Co (Mr. R. Sarikkola) and the Myllykoski Co (Mr. M. Tyni) for placing the primary material at their disposal. We would also thank the Department of Electron Optics (Mr. S. Sivonen) for the microprobe analyses. The manuscript was translated into English by Mr. Malcolm Hicks. Special thanks are due Mrs. Pirkko Paulasuo and Mrs. Kristiina Karjalainen for drawing the figures. 


\section{References}

Alapieti, T., 1982. The Koillismaa layered igneous complex, Finland - its structure, mineralogy and geochemistry, with emphasis on the distribution of chromium. Geol. Surv. Finland, Bull. 319, 116 p.

-; Hugg, R. \& Piirainen, T., 1979a. Structure, mineralogy and chemistry of the Syöte section in the Early Proterozoic Koillismaa layered intrusion, northeastern Finland. Geol. Surg. Finland, Bull. 299, 43 p.

-; Hugg, R.; Piirainen, T. \& Ruotsalainen, A., 1979b. The ultramafic and mafic intrusion at Näränkävaara, northeastern Finland. Geol. Surv. Finland, Rept. Invest. 35, $31 \mathrm{p}$.

— \& Piirainen, T., 1984. Cu-Ni-PGE mineralization in the marginal series of the Early Proterozoic Koillismaa layered igneous complex, northeastern Finland. In: Buchanan, D. L. and Jones, M. L. (eds.), Sulphide Deposits in Mafic and Ultramafic Rocks. Inst. Min. Metall., London, pp. 123-131.

- \& Sivonen, S., 1983. Use of the electron microprobe in the investigation of the Early Proterozoic Koillismaa layered igneous complex, NE Finland. Geol. Surv. Finland, Rept. Invest. 61, 22 p.

Borchert, H., 1954. Kritische Bemerkungen zu zwei neuen Arbeiten über Outokumpu, Finnland. Zeitschr. Erzberg. Metall., 7, 82-84.

Bowes, D. R.; Halden, N. M.; Koistinen, T. J. \& Park, A. $F$., 1984. Structural features of basement and cover rocks in the eastern Svecokarelides, Finland. In Kröner, A. and Greiling, R. (eds.), Precambrian Tectonics Illustrated. Schweizerbart'sche Verlagsbuchhandlung, Stuttgart, pp. $147-171$.

Burgath, K. P.; Mohr, M.; Rammlmair, D. \& Steiner, L., 1986. Petrography, geochemistry and structural development of a large number of chromite occurrences in the Oman ophiolite. In Galkegher, M. J.; Ixer, R. A.; Neary, C. R. and Prichard, H. M. (eds.), Metallogeny of Basic and Ultrabasic Rocks. Inst. Min. Metall., London, pp. 199-228.

Christodoulou, C. \& Hirst, D. M., 1985. The chemistry of chromite from two mafic-ultramafic complexes in Northern Greece. Chem. Geol. 49, 415-428.

Dick, H. J. B., 1977. Partial melting in the Josephine Peridotite I, the effect on mineral composition and its consequence for geobarometry and geothermometry. Am. J. Sci. 277, 801-832.

— \& Bullen T., 1984. Chromian spinel as a petrogenetic indicator in abyssal and Alpine-type peridotites and spatially associated lavas. Contrib. Mineral. Petrol. 86, $54-76$.

Dickey, J. S., Jr., 1975. A hypothesis of origin for podiform chromite deposits. Geochim. Cosmochim. Acta 39, $1061-1075$.
Eskola, P., 1933. On the chrome minerals of Outokumpu. Bull. Comm. géol. Finlande 103, 26-44.

Fleet, M. E.; MacRae, N. D. \& Herzberg, C. T., 1977. Partition of nickel between olivine and sulfide: A test for immiscible sulfide liquids. Contrib. Mineral. Petrol. 65, 191-197.

Frosterus, B., 1902. Bergbyggnaden i sydöstra Finland. Deutsches Referat. Der Gesteinsaufbau des südöstlichen Finnland. Bull. Comm. géol. Finlande 13, 168 p.

— \& Wilkman, W. W., 1920. Vuorilajikartan selitys, lehti D 3, Joensuu. Suomen geologinen yleiskartta, $1: 400000$. Geologinen toimikunta, Helsinki.

Frey, F. A., 1984. Rare earth element abundances in upper mantle rocks. In Henderson, P. (ed.), Rare Earth Element Geochemistry. Elsevier, Netherlands, pp. 153-203.

Gaál, G., 1964. Jatul und karelische Molasse im S-Koligebiet in Nordkarelien und ihre Beziehungen zum Gebirgsbau des präkambrischen Orogens. Bull. Comm. géol. Finlande 213, 45 p.

—; Koistinen, T. J. \& Mattila, E., 1975. Tectonics and stratigraphy of the vicinity of Outokumpu. N. Karelia, Finland. Geol. surv. Finland, Bull. 271, 1-67.

Greenbaum, D., 1977. The chromitiferous rocks of the Troodos Ophilolite Complex, Cyprus. Econ. Geol. 72, 1175-1194.

Haapala, P., 1936. On serpentine rocks in Northern Karelia. Bull. Comm. géol. Finlande, 114, 83 p.

Hanski, E., 1986. The Gabbro-Wehrlite Association in the Eastern Part of the Baltic Shield. In Friedrih, G. H., et al. (eds.), Geology and Metallogeny of Copper Deposits. Springer-Verlag. Berlin, Heidelberg, pp. 151-170.

Hoffman, M. A. \& Walker, D., 1978. Textural and chemical variations of olivine and chrome spinel in the East Dover Ultramafic Bodies, South-Central Vermont. Geol. Soc. Am., Bull. 89, 699-710.

Hoffman, P.; Dewey, J. F. \& Burke, K., 1974. Aulacogens and their genetic relation to geosynclines, with a Proterozoic example from Great Slave Lake, Canada. In Dott, R. H. and Shaver, R. H. (eds.), Modern and Ancient Geosynclinal Sedimentation. Soc. Econ. Paleont. Miner., Spec. Publ. 19, 38-55.

Huhma, A., 1971. Maps of Pre-Quarternary rocks: 4222 Outokumpu, 4224 Kontiolahti and 4311 Sivakkavaara. Geol. map of Finland 1 : 100 000. Geol. Survey of Finland.

—, 1975. Precambrian rocks of the Outokumpu, Polvijärvi and Sivakkavaara map sheets. 1: 100000 (Summary in English). Geologinen Tutkimuslaitos, Espoo, 131 p.

,- 1976 . New aspects to the geology of the Outokumpu region. Bull. Geol. Soc. Finland 48, 5-24.

— \& Huhma, M., 1970. Contributions to the geology of the Outokumpu region. Bull. Geol. Soc. Finland 42, 57-88.

Huhma, H., 1986. Sm-Nd, U-Pb and $\mathrm{Pb}-\mathrm{Pb}$ isotopic evidence for the origin of the Early Proterozoic Svecokarelian crust 
in Finland. Geol. Surv. Finland, Bull. 337, 48 p.

Irvine, T. N., 1967. Chromian spinel as a petrogenetic indicator, Part 2. Petrologic applications. Can. J. Earth Sci. 4, $71-103$.

Jankovic, S., 1986. General features of chromite deposits and major ore districts in Yugoslavia. In Karamata, S. (ed.), Chromites. Unesco's IGCP-197 Project. Metallogeny of ofiolites. Theophrastus publ., Athens, pp. 67-90.

Johan, Z. \& Auge, T. 1986. Ophiolitic mantle sequences and their evolution: mineral chemistry constraints. In Galkegher, M. J., Ixer, R. A., Neary, C. R. and Prichard, H. M. (eds.), Metallogeny of Basic and Ultrabasic Rocks. Inst. Min. Metall., London, pp. 305-319.

Kohonen, J., 1987. Jatulimuodostumien paleosedimentologia Herajärven alueella Pohjois-Karjalassa. PohjoisKarjalan malmiprojekti, Oulun yliopisto. Raportti Nro 6, $150 \mathrm{p}$.

Koistinen, T. J., 1981. Structural evolution of an Early Proterozoic strata-bound $\mathrm{Cu}-\mathrm{Co}-\mathrm{Zn}$ deposit, Outokumpu, Finland. Trans. R. Soc. Edinb. Earth Sci. 72, 115-158.

—, 1986. The Outokumpu ore district, east Finland, a closed basin. In Sokolov, V. A., Heiskanen, K. I. (eds.), Early Proterozoic of the Baltic Shield. Proc. Finnish Soviet Symposium, 19th-27th August, 1985, Petrozavodsk. Petrozavodsk, Karelskii Filial AN SSSR, pp. 104-112.

,- 1987 . Review of the geology of North Karelia. Geol. Surv. Finland, Spec. Pap. 1, 35-40.

Kontinen, A., 1987. An early Proterozoic ophiolite - the Jormua mafic-ultramafic complex, northeastern Finland. Precambrian Res. 35, 313-341.

Leblanc, M. \& Violette, J. F., 1983. Distribution of aluminium-rich and chromium-rich chromite pods in ophiolite peridotite. Econ. Geol. 78, 293-301.

Malpas, J. \& Strong, D. F., 1975. A comparison of chrome spinels in ophiolites and mantle diapirs of Newfoundland. Geochim. Cosmochim. Acta 39, 1045-1060.

Marmo, J.; Kohonen, J.; Sarapää, O. \& Äikäs, O., 1988. Sedimentology and Stratigraphy of the Lower Proterozoic Sariola and Jatuli groups in the Koli-Kaltimo Area, eastern Finland. In Laajoki, K. and Paakkola, J. (eds.), Sedimentology of the Bedrock of Finland. Geol. Soc. Finland., Spec. Paper 5, 11-28.

Mäkelä, M., 1974. A study of sulphur isotopes in the Outokumpu ore deposits. Geol. Surv. Finland, Bull. 267, 45 p.

Mäkelä, K., 1981. On the potential of finding Outokumputype ore deposits in East- and North-Finland (English summary). Geologi 33, 20-22.

Obradvic, L. J., 1986. Short review of the chemistry of chromites from Brezovica, Yogoslavia. In: Karamata, S. (ed.), Chromites. Unesco's IGCP-197 Project. Metallogeny of ophiolites. Theophrastus publ., Athens., pp. 91-106.

Papunen, H., 1987. Outokumpu-type ores. Geol. Surv. Finland. Spec. Pap. 1, 41-50.

Park, A. F., 1984. Nature, affinities and significance of metavolcanic rocks in the Outokumpu assemblage of eastern Finland. Bull. Geol. Soc. Finland. 56, 25-52.

—, 1988. Nature of the Early Proterozoic Outokumpu assemblage, Eastern Finland. Precambrian Res. 38, $131-146$.

— \& Bowes, D. R., 1981. Metamorphosed and deformed pillows from Losomäki: evidence of sub-aqueous volcanism in the Outokumpu association, eastern Finland. Bull. Geol. Soc. Finland 53, 135-145.

Parkkinen, J. \& Reino J., 1985. Nickel occurrences of the Outokumpu type at Vuonos and Keretti. Geol. Surv. Finland, Bull. 333, 178-188.

Patchett, P. J.; Kouvo, O.; Hedge, C. E. \& Tatsumoto, M., 1981. Evolution of continental crust and mantle heterogeneity: evidence from isotopes. Contrib. Mineral. Petrol. 78, 279-297.

Pekkarinen, L. J., 1979. The Karelian formations and their depositional basement in the Kiihtelysvaara-Värtsilä area, East Finland. Geol. Surv. Finland, Bull. 301, 141 p.

Peltola, E., 1978. Origin of Precambrian copper sulfides of the Outokumpu district, Finland. Econ. Geol. 73, $461-476$.

Piirainen, T., 1968. Die Petrologie und die Uranlagerstätten des Koli-Kaltimogebiets im finnischen Nordkarelien. Bull. Comm. Géol. Finlande 237, 99 p.

—, 1969. Initialer Magmatismus und seine Erzbildung in der Beleuchtung des Koli-Kaltimogebiets. Bull. Geol. Soc. Finland 41, 21-45.

—, 1976. Kolin alueen kallioperä ja sen suhde svekokarjalaiseen vuorijonoon: Stratigrafiasymposio 08.09. 1976. Suomen Geologinen Seura, Geologiliitto r.y. koulutusmoniste nro 2.

—; Honkamo, M. \& Rossi, S., 1974. A preliminary report on the geology of the Koli area. Bull. Geol. Soc. Finland $46,161-166$.

Prinzhofer, A. \& Allégre, C. J., 1985. Residual peridotites and the mechanisms of partial melting. Earth Planet. Sci. Lett. 74, 251-265.

Rammlmair, D., 1986. Chromite in the Philippines: Its relationship to the tectonic setting of the host ophiolites; examples from Zambales and Palawan. In Karamata, S. (ed.), Chromites. Unesco's IGCP-197 Project. Metallogeny of ophiolites. Theophrastus publ., Athens., pp. 285-310.

Rehtijärvi, P. \& Saastamoinen, J., 1985. Tectonized actinolite - albite rocks from the Outokumpu district, Finland: field and geochemical evidence for mafic volcanism. Bull. Geol. Soc. Finland 57, 47-54.

Sakko, M., 1971. Radiometric zircon ages on the EarlyKarelian metadiabases. Geologi 23, 117-118.

Simkin, T. \& Smith, J. V., 1970. Minor-element distribution in olivine. J. Geol. 78, 304-325.

Simonen, A., 1980. The Precambrian in Finland. Geol. Surv. Finland, Bull. 304, 58 p. 
Stevens, R. E., 1944. Composition of some chromites of the western hemisphere. Am. Mineral. 29, 1-34.

Tankut, A., 1980. The Orhaneli massif, Turkey. In Panayiotau, A. (ed.), Ophiolites. Proceedings International Ophiolite Symposium, Cyprus 1979, Cyprus Geol. Surv. Dep. pp. 702-713.

Treloar, P. J., 1987. The Cr-mineral of Outokumpu - their chemistry and significance. J. Petrol. 28, 867-886.

—; Koistinen, T. J. \& Bowes, D. R., 1981. Metamorphic development of cordierite-amphibole rocks and mica schists in the vicinity of the Outokumpu ore deposit, Finland. Trans. R. Soc. Edinb. Earth Sci. 72, 201-215.

Trüstedt, O., 1921. Över geologin inom Outokumpu området. Medd́. Geol. fören. i Helsingfors 1919-1920, p. 16.

Vance, J. A. \& Duncan. M. A., 1977. Formation of peridotites by deserpentinization in the Darrington and Sultan areas, Cascade Mountains, Washington. Geol. Soc. Am. Bull. 88, 1497-1508.

Ward, P. G., 1987. Early Proterozoic deposition and deformation at the Karelian craton margin in southeastern Finland. Precambrian Res. 35, 71-93.

Wegmann, C. E., 1928. Über die Tektonik der jüngeren Fal- tung in Ostfinnland. Fennia 50, 1-22.

Vuollo, J. I., 1986. Värriöjoen ultraemäksisen intruusion petrografia, mineralogia ja geokemia. Unpubl. M. Sci. Thesis, Dept. Geol. Univ. Oulu. 108 p.

—, 1988. Kolin kerrosjuonen petrologia - Kaunisniemen profiili. Pohjois-Karjalan malmiprojekti, Oulun yliopisto. Raportti No 16, 122 p.

Vähätalo, V., 1953. On the geology of the Outokumpu ore deposit in Finland. Bull. Comm. Géol. Finlande 164, 91 p.

Väyrynen, H., 1933. Über die Stratigraphie der karelischen Formationen. Bull. Comm. Géol. Finlande 101, 54-78.

—, 1937. On the tectonics of the Karelian zone. XII Int. Geol. Congr. pp. $57-70$.

,- 1939 . On the geology and tectonics of the Outokumpu ore field and region. Bull. Comm. Géol. Finlande 124, $91 \mathrm{p}$.

-, 1954. Suomen kallioperä. Sen synty ja geologinen kehitys. Otava, Helsinki. 260 p.

Received November 11, 1988

Revision accepted February 2, 1989 